\title{
Comparing Online And In-Class Students: Perceptions, Demographics And Grades In MBA Accounting Classes
}

Thomas Tribunella, (E-mail: ttribunella@cob.rit.edu), Rochester Institute of Technology

\begin{abstract}
In this study, graduate business students participated in an accounting course that was offered online and in-class. The students worked in groups on an accounting case study. Data collected from both online and on-campus classes were reported, compared, and analyzed. Learning outcomes were investigated in relation to content knowledge, academic performance, fairness, and educational objectives based on Bloom's Taxonomy. As a result, only small differences were found in the learning outcome measures between online and in-class students. However, input measures indicate that the online students may have been better prepared for the course.
\end{abstract}

\section{Introduction}

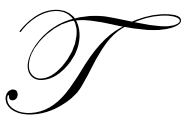

he number of students studying online is increasing rapidly. Online enrollment grew from at 1.6 million in 2000 to 3 million in 2001 according to the US Department of Education (Gagne \& Shepherd 2001). A Sloan study (Allen \& Seaman 2003) reported that $81 \%$ of US colleges were offering online courses by 2002 (Conhaim 2003). The Sloan Consortium reports that online education will continue to grow at a $20 \%$ rate (Roach 2003). For example, the State University of New York Learning Network (SLN) has experienced substantial growth (SLN 2002) over the last several years:

Exhibit 1: Growth of Online Education in the SUNY Learning Network

\begin{tabular}{|l|c|c|c|c|c|c|c|c|}
\hline \multicolumn{1}{|c|}{ Year } & $\mathbf{1 9 9 5 - 9 6}$ & $\mathbf{1 9 9 6 - 9 7}$ & $\mathbf{1 9 9 7 - 9 8}$ & $\mathbf{1 9 9 8 - 9 9}$ & $\mathbf{1 9 9 9 - 0 0}$ & $\mathbf{2 0 0 0 - 0 1}$ & $\mathbf{2 0 0 1 - 0 2}$ & $\mathbf{2 0 0 2 - 0 3}$ \\
\hline $\begin{array}{l}\text { SUNY Schools Offering } \\
\text { Online Classes }\end{array}$ & 2 & 8 & 20 & 37 & 42 & 47 & 53 & 57 \\
\hline Courses & 8 & 34 & 180 & 460 & 1,000 & 1,500 & 2,525 & 3,100 \\
\hline Students & 119 & 460 & 2,060 & 6,060 & 13,000 & 25,814 & 38,848 & 48,000 \\
\hline Degree Programs & 0 & 0 & 0 & 4 & 12 & 40 & 56 & 60 \\
\hline Student Satisfaction & $*$ & $*$ & $*$ & $88 \%$ & $85 \%$ & $86 \%$ & $88 \%$ & $88 \%$ \\
\hline
\end{tabular}

* Data not collected for that period.

The rapid growth rate raises the importance of concerns regarding the quality, effectiveness and efficiency of online learning. This study examines the differences and similarities of the learning perceptions and achievement of traditional students with online students. Specifically, this research compares students in a MBA accounting course for lower and higher level thinking skills. The contributions of this study are two fold. First, it examines students in the context of an accounting course which has only been done in one other study. Secondly, it compares online with traditional learning on higher and lower order thinking skills as defined by Bloom's Taxonomy.

There are several important differences between online education and learning in a traditional classroom setting. In an online class, the professor and students communicate with each other primarily over the Internet or World Wide Web (WWW). Students and professors can be located anywhere in the world and the class participants 
are usually not interacting synchronously. The following matrix summarizes the various combinations of location, time, and privacy as they relate to education:

Exhibit 2: Synchronous vs. Asynchronous Teaching

\begin{tabular}{|c|c|c|c|c|}
\hline Class Timing & Same Location & Different Location & Private Communication & Public Communication \\
\hline Synchronous (Same Time) & Classroom & Video Conference & Phone, Instant Messaging & Chat Room \\
\hline Asynchronous (Different Time) & Lab & Most Online Courses & E-mail & Threaded Discussion \\
\hline
\end{tabular}

Synchronous class timing requires all the participants to be interacting simultaneously. The students and the professor can interact with each other at a point in time through a chat room, instant messaging or video conference. Asynchronous class timing does not require all the participants to be interacting simultaneously. The students and the professors can interact with each other independently over a period of time through a list-serve and threaded discussions. A threaded discussion is a group of related messages organized around the same topic. The title of the thread should clearly indicate the subject being discussed. Threads list all of the interactions by discussants in order of sequence. Students generally accept asynchronous threaded discussions as a viable method for communicating when the instructor facilitates class participation (Rovai 2001).

A 1999 survey of SUNY Learning Network students shows more than 88\% (see Exhibit 1) of the asynchronous online students were satisfied or very satisfied with courses offered by 37 different colleges and universities of the State University of New York (SUNY). Ninety-one percent of students said they would consider taking another online course in the future. The survey involved over 1,900 students who took SUNY Learning Network (SLN) courses in the 1998-99 academic year which represents a 31\% response rate (SLN 2002).

I have observed from anecdotal inquiries that some accounting and business instructors believe that physical human interaction is an important variable for effective education. Some critics of online education believe quality control is a significant problem (Tribune Newspapers 2003). Studies show that professors have a negative bias toward online education and are skeptical about its effectiveness (Wang, MacArthur \& Crosby 2003). In spite of its popularity with students, most online instruction does not allow for physical human contact. During online instruction, the computer filters out all direct physical human interaction. This raises interesting research questions regarding the quality, effectiveness and efficiency of online courses and the measurement of Internet based learning.

\section{Literature Review}

Literature in this area can be classified into four categories: student perceptions of learning, faculty perceptions of student learning, student achievement measured by grades, and the degree of class participation. Generally, the literature suggests there are no significant differences in learning outcomes between traditional and online students.

In the survey data, $90 \%$ of the cyber-learners believed they learned as much or more as they would have in a traditional classroom (Navarro \& Shoemaker 1999). The student perception of online education being equal in quality to in-class education has been verified by several studies (Beard \& Harper 2002); (Ryan 2000); (Tribunella 2003); (Nichols \& Shaffer 2003).

With respect to exam data, there were no significant differences in the test scores between online and inclass students for the same classes with the same instructor giving the same exam (Clarke 1999). In a similar study, results from t-tests indicated that online and in-class students achieved approximately the same level as measured by test scores. Some research work incorporates an examination of lecture delivery methods. This research postulates that when virtual lectures are used in place of traditional delivery methods there is no significant difference in attainment level as measured by end of year examinations (Smeaton \& Keogh 1999). 
However, research that studied pretest scores reported that the group of students who self-selected into online courses, scored higher than the in-class students. This result is an indication that the students who select online courses may be better prepared for the course material than the students who select in-class courses. This preparedness may not lead to greater learning since there were no significant differences between the two groups of students on their posttest scores (Schulman \& Sims 1999).

In a 1999 study, $85 \%$ of faculty reported that student learning outcomes in online education were equal to or greater than those found in face-to-face classrooms. These faculty members had experience teaching the same course in face-to-face and in online environments (Dobrin 1999). Other research studies posit similar results, faculty reported that learning outcomes in online education are comparable to $(62 \%)$ or better than $(23 \%)$ those of face-to-face courses. Eighty-five percent of faculty teaching online said their students learned as effectively as oncampus students (Hoffman 1999). A survey of 3,000 college presidents and chief academic offices (almost 1,000 replied) by the Sloan Consortium reports that $57 \%$ believe their online course are at least of equivalent quality as traditional courses offered at their institutions (The Chronicle of Higher Education 2003).

Finally, research has demonstrated that online instructors, who use teaching methods that promote student-faculty interaction, facilitate stronger communities among online learners (Rovai 2001). The strength of an online community is measured by the quantity and depth of discussion treads. This research has also shown that female students tend to participate more frequently then male students (Rovai 2001).

\section{Goals of this Study}

This research contributes to the literature by examining potential differences between online and traditional students with regards to their performance in graduate level MBA accounting classes. This paper builds on the work published by Gagne and Shepherd (GS) who studied distance learning in accounting (2001). GS reported that pretest scores were higher for online students but posttest scores and case study grades were similar for online and in-class students. In addition, GS found that quality perceptions based on student surveys were the same. This paper replicates that prior research and adds an analysis of learning based on Bloom's taxonomy, student withdrawal rates, and a comparison of the time students worked on a complex case study.

Conspicuously absent from the literature are investigations of the learning differences organized by higher and lower level thinking skills. Accounting is an interesting context for this study because it incorporates a content that includes a large quantity both of lower and higher level thinking skills. To this end, a case study that required students to analyze a value chain in a production environment was used as a learning tool with accounting and business students.

This study contributes to the literature by measuring student perceptions of learning with regards to the components of Bloom's taxonomy. Student perceptions, demographics and grades are investigated where the case study questions and exam questions were organized according to Bloom's taxonomy of thinking skills. Objective feedback from online and in-class students were compared and contrasted for similarities and differences.

The findings reported in this paper should be of particular interest to accounting and business professors who are considering online teaching. They may use the findings to improve their courses by understanding the differences and similarities between online and in-class learning. This study could also help administrators assess the potential strengths and weakness of Internet based education. In addition, it may help them develop curricula and programs that have online components.

\section{Bloom's Taxonomy of Educational Objectives}

The study required students to apply Bloom's hierarchy of lower-order thinking skills (knowledge and comprehension) and higher-order thinking skills (application, analysis, synthesis, and evaluation) to the case material (Bonner 1999), (Gainen \& Locatelli 1995). This section contains brief explanations of the components of 
Bloom's taxonomy (Bloom, Engelhart, Furst, Hill, \& Krathwohl 1956). Exhibit 3 summarizes Bloom's taxonomy and its relationship to higher order and lower order thinking skills.

Exhibit 3: Bloom's Taxonomy of Thinking Skills

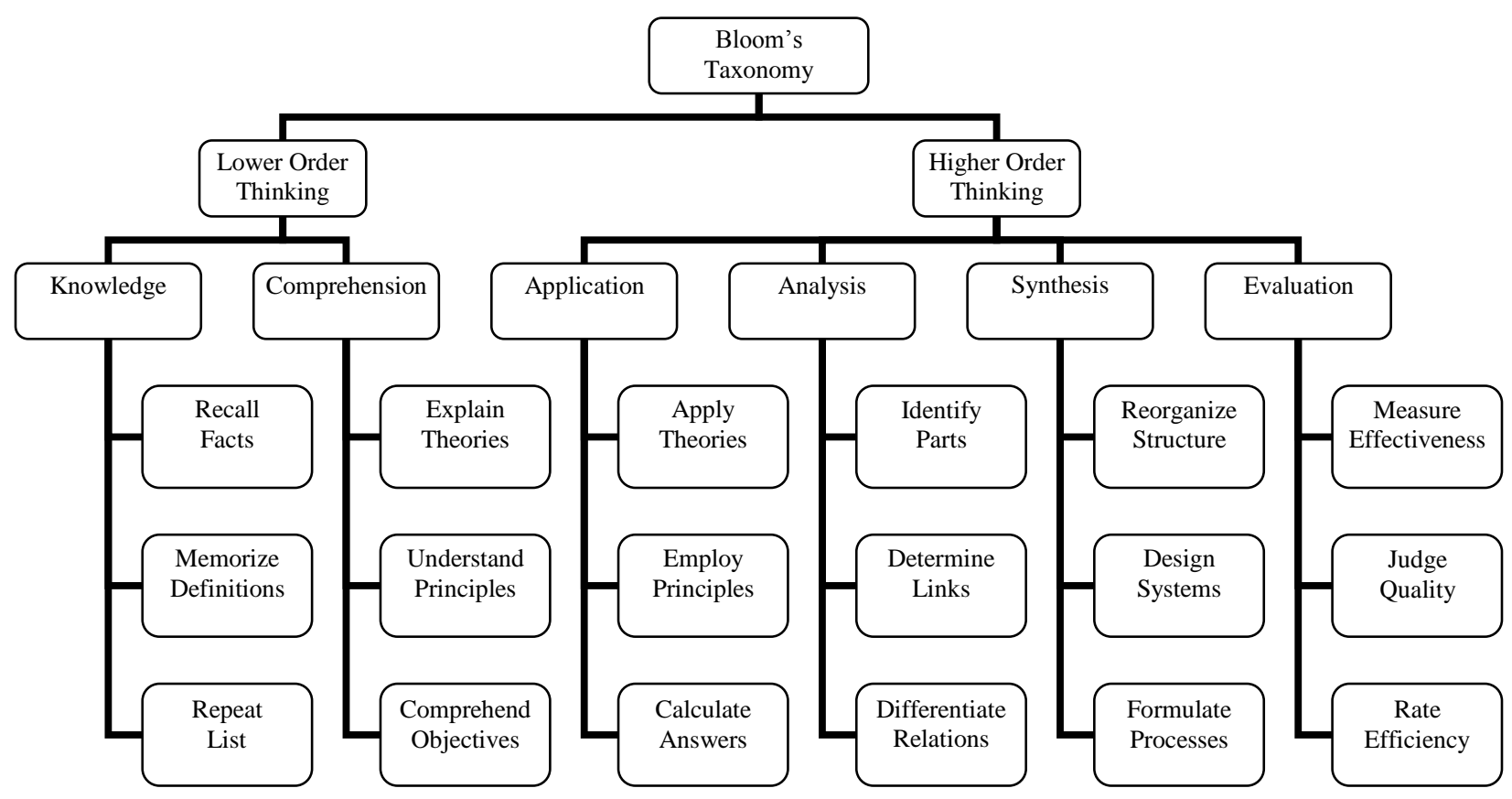

Lower order thinking skills consist of knowledge and comprehension. Knowledge involves simple recall and memorization as well as bringing to mind appropriate facts or definitions. Key words in knowledge-related assignments include define, list, name, repeat, record, relate, state, and underline.

Comprehension requires students to put definitions into their own words. It is a lower-order skill that includes knowledge of principles and theories. Key words in comprehension-related assignments are; describe, explain, express, identify, locate, recognize, report, restate, tell, and translate.

Higher order thinking skills consist of application, analysis, synthesis and evaluation. Application requires students to employ concepts or principles, including the selection and use of general rules, procedures, and methods for specific situations. Application involves the process of manipulating information to obtain a particular result. Key words in application-related assignments are utilize, demonstrate, dramatize, employ, illustrate, interpret, operate, practice, schedule, sketch, use, compute, calculate, format, compile, and apply.

Analysis is the decomposition of an organized structure to identify its parts, their relationships, and their organizational principles. It involves the ability to reorganize the structure. Key words included in analysis assignments are: analyze, appraise, categorize, compare, contrast, critique, debate, determine, differentiate, distinguish, examine, experiment, inventory, inspect, link, question, solve, and test.

Synthesis involves putting together elements and parts to form a new whole. This includes working with pieces, principles, rules, and organizing them into a new structure. Key words in synthesis assignments are; arrange, assemble, collect, compose, construct, create, design, formulate, manage, organize, plan, prepare, propose, and set up. 
Evaluation involves judgments about the value of data, materials, results or methods. It includes quantitative and qualitative judgments in relation to both obvious and obscure criteria. Key words related to evaluation assignments are appraise, assess, choose, compare, estimate, evaluate, judge, measure, rate, review, revise, score, select, and value.

\section{Research Design and Methodology}

\section{Subjects}

The study was conducted in four sections of a graduate course titled "Accounting for Managers". Two categories of graduate students participated in the study, two sections of asynchronous online and two sections of traditional students. The sample of 105 students self selected into either online or in-class sections. The sample was based on convenience selection and not randomized.

The same professor taught all sections of the course. Identical exams, lecture content, text book and case study assignments were used in all of the course sections. The professor, who had 15 years of experience, utilized the same discussion questions, academic expectations and level of rigor in all four course sections. The participants worked on a case study in groups of consulting teams that included two or three students. Data was collected through voluntary participation on a 21 item attitudinal survey rated on a five-point Likert scale (the survey is displayed in Appendix I). Academic data was provided by the professor and the registrar's office.

\section{Research and Survey Design}

Faculty members were used to pretest the survey which is displayed in Appendix I. The survey was distributed to five professors who examined and tested the survey for time, clarity, relevance and understandability according to methods prescribed by Alreck \& Settle (1995). The survey was adjusted to incorporate several suggested improvements. In addition to survey data, grading results were collected from the final exam. The data collection and analysis was developed around the following six areas:

- $\quad$ Delivery Mode and Timing: online vs. in-class students participated over four semesters (see Exhibit 4).

- Participant Profiles: three measures consisting of major, grade point average (GPA), and years of professional work experience (see Exhibit 4).

- $\quad$ Academic Results: four measures including time worked on case, case grade, number of withdrawals from the course sections, and the average score on seven multiple choice questions included on the final exam and related to the case content material (see Exhibit 4).

- Understandability, Fairness and Overall Evaluation: eight survey questions based on a Likert scale (see Exhibit 7).

- $\quad$ Content Based Learning Objectives: five survey questions related to subject content based on a Likert scale (see Exhibit 8).

- $\quad$ Bloom's Educational Objectives: six survey questions related to learning outcomes based on a Likert scale (see Exhibit 9).

"Participant Profiles" were taken at the beginning of each semester and "Academic Results" were measured at the end of the course. The multiple choice (MC) scores were based on the percent of correct answers on seven questions included on the final exam. The MC questions tested lower level thinking skills related to the subject content covered in the case. The case focused on higher level thinking skills and all of the cases were graded by the same professor using a consistent evaluation method.

A survey was distributed at the end of the course. The survey scores were collected from questions related to self perceived measures. To determine whether the students perceived the case as meeting the stated objectives they were asked to answer questions using the five point Likert scale displayed below: 


\begin{tabular}{c|c|c|c|c}
1 & 2 & 3 & 4 & 5 \\
\hline Strongly disagree & Disagree & Neutral & Agree & Strongly agree
\end{tabular}

The case titled Sun Mountain Systems, integrates value chain analysis (Porter 1991) in a production environment. Students are asked to redesign a batch system production process to increase efficiency and eliminate non-value-added steps. The case utilized higher level thinking because it required student to analyze a production process, apply value chain analysis, reassemble the process, and judge the effectiveness of their suggested improvements. Students were also required to apply cost-volume-profit calculations in the context of judging the effectiveness of the value chain analysis. The realistic feel of the case is enhanced by the use of data that reflects industry averages (Troy 2001).

To compare groups for significant differences, the data were divided into two nominal categories: online and in-class. Data collected from both online and in-class students will be reported, compared, and analyzed.

\section{Results}

\section{Demographics and Descriptive Statistics}

The data was collected over four semesters starting in fall 2001 and ending in the spring semester of 2003. One hundred and five students answered the survey questions, producing a 94.6\% (105/111) response rate. Exhibit 4 displays student profiles, academic information and the survey timing.

Exhibit 4: Participate Profiles \& Academic Results - Online vs. In-Class

\begin{tabular}{|c|c|c|c|}
\hline & In-Class & Online & \\
\hline Delivery Mode and Survey Timing: & & & Total \\
\hline Fall 2001 & & 20 & 20 \\
\hline Spring 2002 & 19 & & 19 \\
\hline Fall 2002 & & 39 & 39 \\
\hline Spring 2003 & 27 & & 27 \\
\hline All Students & 46 & 59 & 105 \\
\hline \multicolumn{4}{|l|}{ Participate Profiles: } \\
\hline Accounting Majors & 6 & 19 & 25 \\
\hline Non-accounting Majors & 40 & 40 & 80 \\
\hline Participate Profiles: & & & Average \\
\hline Percent of Accounting Majors $*$ & $13.0 \%$ & $32.2 \%$ & $23.8 \%$ \\
\hline Professional Experience In Years $* *$ & 3.70 & 5.49 & 4.70 \\
\hline Average GPA & 3.57 & 3.51 & 3.54 \\
\hline Academic Results: & & & Average \\
\hline Work Time On Case In Hours ** & 5.71 & 9.20 & 7.65 \\
\hline Average Scores on Selected MC Exam Questions & $95.9 \%$ & $92.9 \%$ & $94.2 \%$ \\
\hline Withdrawals * & $4.3 \%$ & $15.3 \%$ & $10.5 \%$ \\
\hline Case Grades & $86.9 \%$ & $81.2 \%$ & $83.7 \%$ \\
\hline
\end{tabular}

There are several areas of comparison that are interesting. In general, students with high levels of professional work experience and accounting majors were attracted to the online format. However, online students did not score higher grades on the case even after spending significantly more time working on the case. 


\section{Hypotheses and Statistical Tests}

The homogeneity of variance for survey question answers was tested using an F distribution and Levene's Test (Stevens 1986). The following hypotheses were tested:

- Null hypothesis $\left(H_{0}\right)$ : The variances of survey question answers for online students are equal to the variances of survey question answers of in-class students.

- $\quad H_{0}: \sigma_{1}^{2}=\sigma_{2}^{2}$ or $\sigma_{1}^{2}-\sigma_{2}^{2}=0$

- $\quad$ Alternative hypothesis $(H \alpha)$ : The variances of survey question answers for online students are not equal to the variances of survey question answers of in-class students.

- $\quad H \alpha: \sigma_{1}^{2} \neq \sigma_{2}^{2}$

- Where: $\sigma_{1}^{2}$ represents the variances of online student answers and $\sigma_{2}^{2}$ represents the variances of in-class student answers.

The tests related to the variances of survey question answers for question 2, 5, 6, 7, 12, 16, 18, and 19 resulted in rejecting the null hypothesis with $95 \%$ confidence. In these cases, adjusted t-scores will be used for testing the equality of means between online and in-class participants (see Exhibit 6 to review adjusted t-scores).

The next procedure related to testing the equality means between online and in-class students. The following hypotheses were tested:

- $\quad$ Null hypothesis $\left(H_{0}\right)$ : The means of survey question answers for online students are equal to the means of survey question answers of in-class students.

- $\quad H_{0}: \mu_{1}=\mu_{2}$ or $\mu_{1}-\mu_{2}=0$

- $\quad$ Alternative hypothesis $(H \alpha)$ : The means of survey question answers for online students are not equal to the means of survey question answers of in-class students.

- $\quad H \alpha: \mu_{1} \neq \mu_{2}$

- Where: $\mu_{1}$ represents the means of online student answers and $\mu_{2}$ represents the means of in-class student answers

All 19 of the survey question answers related to learning objectives are negatively skewed. The skewness measures ranged from -1.071 to -.014 for the 19 questions based on a Likert scale. Since the skew of the distribution is negative, this implies that there are relatively more high responses on the Likert scale (1 through 5) than low responses (Judd, Smith and Kidder 1991). Distributions with skew scores equal to or less than -1 (see Exhibits 5 and 6 for skew scores) will be retested with non-parametric statistics which do not assume normality (Hinkle, Wiersma and Jurs 1988). The results of the hypothesis tests for the equality of means are reported by category in the following sections.

\section{Participant Profiles}

Since some researchers posit that self selected online students are better prepared for the course material than in-class students (Schulman \& Sims 1999); (Amlie 2002), academic information was collected about the students before they participated in the study. Specifically, student grade point averages (GPA), percent of accounting majors, and work experience were compared between online and in-class participants. This information was used as an approximation to ascertain if the two groups of students were academically similar before they began the course.

The student GPAs were not normally distributed since they had a skew measure of -1.61 (see Exhibit 5). Accordingly, non-parametric tests were employed. There was no significant difference between online student GPAs and in-class student GPAs using Mann-Whitney U and Wilcoxon W tests with 95\% confidence. 
Exhibit 5: Variance Tests, Mean Tests and Skew Measures for Profiles \& Academic Results

\begin{tabular}{|c|c|c|c|c|c|c|}
\hline \multirow[t]{2}{*}{ Description } & \multirow[t]{2}{*}{$\begin{array}{c}\text { Equality of Variance } \\
\text { Assumptions } \\
\end{array}$} & \multicolumn{2}{|c|}{$\begin{array}{c}\text { Levene's Test for Equality } \\
\text { of Variances }\end{array}$} & \multicolumn{2}{|c|}{ t-test for Equality of Means } & \multirow[t]{2}{*}{ Skew } \\
\hline & & $\mathbf{F}$ & Sig. & $\mathbf{t}$ & Sig. (2-tailed) & \\
\hline \multicolumn{7}{|l|}{ Profile: } \\
\hline Experience & assumed & 18.905 & .000 & 2.631 & .010 & .366 \\
\hline Experience & not assumed & & & 2.751 & .007 & \\
\hline GPA & assumed & 8.394 & .005 & -.700 & .486 & -1.610 \\
\hline GPA & not assumed & & & -.738 & .463 & \\
\hline \multicolumn{7}{|l|}{ Results: } \\
\hline Project Work Time & assumed & .342 & .560 & 4.730 & .000 & -.029 \\
\hline Exam Score & assumed & 10.466 & .002 & -1.527 & .130 & -1.818 \\
\hline Exam Score & not assumed & & & -1.608 & .111 & \\
\hline Case Grade & assumed & 8.071 & .005 & -2.061 & .042 & -2.762 \\
\hline Case Grade & not assumed & & & -2.213 & .029 & \\
\hline
\end{tabular}

Ninety-one of the 105 students had professional work experience with an average of 4.7 years. Online students had more professional experience (5.49 vs. 3.7 for in-class students) and the difference is statistically significant using an adjusted t-test with $95 \%$ confidence (see Exhibit 5). An adjusted t-test was employed since the equality of variances test rejected the null hypothesis.

The courses enrolled a mix of 25 accounting and 80 non-accounting majors. A greater number of the online students were accounting majors, $32.2 \%$ vs. $13 \%$ for in-class students. The data are categorical since they classify participates into groups, accounting vs. non-accounting and online vs. in-class. Pearson's Chi-Square and Somers'd tests revealed a strong relationship (95\% confidence) between accounting majors and online studies.

\section{Academic Results}

Exhibit 4 displays the average scores that students earned on seven multiple choice questions related to the material covered in the case study. The scores were not normally distributed since they had a skew measure of 1.818 (see Exhibit 5). As a result, non-parametric tests were employed. There was no significant difference between online student scores and in-class student scores using Mann-Whitney U and Wilcoxon W tests with 95\% confidence. This test was used to add an independent verification of the self-reported learning that was collected on the survey.

Students also reported that they spent an average of 7.65 hours on the case. However, online students reported that they worked harder on the case (9.2 hours vs. 5.71 hours for in class students) and this difference is statistically significant using a t-test with $95 \%$ confidence. Hours worked had a normal distribution and the null hypothesis related to the homogeneity of variances could not be rejected.

In spite of working longer hours on the case, online students scored slightly lower on the case. However, the difference in case grades is not significant using a two tailed t-test with $95 \%$ confidence. In addition, online students withdrew from the accounting course at significantly higher rates.

\section{Overall Learning and Fairness}

Online and in-class student statistics, displayed below in Exhibits 6 and 7, indicate that the participants thought the case was clear, understandable, organized, fair, and useful. However, as a result of skew measures of 1.014 on questions one and -.999 on question five, non-parametric statistics were used to retest the hypothesis related to the equality of means (Kohler 2002), (see Exhibit 6 for skew measures). There were no significant differences between online student answers and in-class student answers using Mann-Whitney U and Wilcoxon W tests with $95 \%$ confidence. 
Exhibit 6: Variance Tests, Mean Tests and Skew Measures for Survey Data

\begin{tabular}{|c|c|c|c|c|c|c|}
\hline \multirow{2}{*}{$\begin{array}{c}\text { Survey Question } \\
\text { Case Understandability: }\end{array}$} & \multirow[t]{2}{*}{$\begin{array}{c}\text { Equality of Variance } \\
\text { Assumptions }\end{array}$} & \multicolumn{2}{|c|}{$\begin{array}{c}\text { Levene's Test for Equality } \\
\text { of Variances }\end{array}$} & \multicolumn{2}{|c|}{ t-test for Equality of Means } & \multirow[t]{2}{*}{ Skew } \\
\hline & & $\mathbf{F}$ & Sig. & $\mathbf{t}$ & Sig. (2-tailed) & \\
\hline Q1 & assumed & .021 & .885 & .619 & .537 & -1.014 \\
\hline $\mathrm{Q} 2$ & assumed & 2.972 & .088 & 1.915 & .058 & -.903 \\
\hline $\mathrm{Q} 2$ & not assumed & & & 1.897 & .061 & \\
\hline $\mathrm{Q} 3$ & assumed & 2.255 & .136 & 1.090 & .278 & -.484 \\
\hline \multicolumn{7}{|l|}{ Case Grading \& Fairness: } \\
\hline $\mathrm{Q} 4$ & assumed & .000 & .993 & -.267 & .790 & -.669 \\
\hline Q5 & assumed & 3.582 & .061 & .447 & .656 & -.999 \\
\hline Q5 & not assumed & & & .478 & .633 & \\
\hline Q6 & assumed & 16.916 & .000 & -1.269 & .207 & -.723 \\
\hline Q6 & not assumed & & & -1.346 & .182 & \\
\hline $\mathrm{Q} 7$ & assumed & 2.770 & .099 & -.831 & .408 & -1.038 \\
\hline \multicolumn{7}{|l|}{ Content Objectives: } \\
\hline Q7 & not assumed & & & -.882 & .380 & \\
\hline Q8 & assumed & .006 & .938 & -.688 & .493 & -.593 \\
\hline Q9 & assumed & 2.554 & .113 & .189 & .850 & -1.071 \\
\hline Q10 & assumed & .472 & .493 & 1.978 & .051 & -.798 \\
\hline Q11 & assumed & .031 & .860 & -.325 & .746 & -.300 \\
\hline \multicolumn{7}{|l|}{ Bloom's Objectives: } \\
\hline Q12 & assumed & 3.516 & .064 & -.013 & .990 & -.708 \\
\hline Q12 & not assumed & & & -.013 & .989 & \\
\hline Q13 & assumed & 1.533 & .219 & .713 & .477 & -.639 \\
\hline Q14 & assumed & 1.387 & .242 & -.170 & .865 & -.311 \\
\hline Q15 & assumed & 1.069 & .304 & 1.647 & .103 & -.014 \\
\hline Q16 & assumed & 3.259 & .074 & .456 & .649 & -.366 \\
\hline Q16 & not assumed & & & .469 & .640 & \\
\hline Q17 & assumed & 2.016 & .159 & -.539 & .591 & -.928 \\
\hline \multicolumn{7}{|l|}{ Overall Evaluation: } \\
\hline Q18 & assumed & 4.330 & .040 & .146 & .884 & -.283 \\
\hline Q18 & not assumed & & & .151 & .880 & \\
\hline Q19 & assumed & 6.893 & .010 & -1.116 & .267 & -.901 \\
\hline Q19 & not assumed & & & -1.149 & .253 & \\
\hline
\end{tabular}

Exhibit 7: Understandability, Fairness and Overall Evaluation - Online vs. In-Class

\begin{tabular}{|c|c|c|c|c|c|}
\hline Survey Question and Number & Mean Online & Mean In- Class & SD Online & SD In- Class & t-Test* \\
\hline \multicolumn{6}{|l|}{ Case Understandability: } \\
\hline 1. The case study was clear. & 3.92 & 3.83 & .749 & .709 & .537 \\
\hline $\begin{array}{l}\text { 2. I was able to understand the case without } \\
\text { significant difficulty. }\end{array}$ & 3.90 & 3.63 & .687 & .741 & .058 \\
\hline 3. The case was well organized. & 3.78 & 3.59 & .852 & .956 & .278 \\
\hline \multicolumn{6}{|l|}{ Case Grading and Fairness: } \\
\hline $\begin{array}{l}\text { 4. The grade percent allocated to the case study was } \\
\text { an appropriate weight given the work required. }\end{array}$ & 3.63 & 3.67 & .849 & .944 & .790 \\
\hline 5. The level of difficulty of the case was appropriate. & 3.92 & 3.87 & .624 & .341 & .656 \\
\hline 6. The case should continue to be used in this course. & 3.85 & 4.04 & .925 & .556 & .207 \\
\hline \multicolumn{6}{|l|}{ Overall Evaluation: } \\
\hline $\begin{array}{l}\text { 18. Overall, I think the SMP case study is a useful } \\
\text { project. }\end{array}$ & 4.08 & 4.07 & .749 & .574 & .884 \\
\hline $\begin{array}{l}\text { 19. The amount of work on the case was justified } \\
\text { based on the learning derived. }\end{array}$ & 3.80 & 3.98 & .906 & .715 & .267 \\
\hline Overall Average & 3.86 & 3.84 & & & \\
\hline
\end{tabular}

* Cannot reject the null hypothesis using a non-directional student's t-test (2 tailed) with $95 \%$ confidence $(\alpha=5 \%)$ unless indicated. 


\section{Content Based Objectives}

Survey results (se Exhibit 8) indicate that students viewed the case as useful and interesting in learning content based knowledge such as value chain analysis (VCA) and contribution margin income (CMI). However, online students reported significantly more progress in understanding the relationship between VCA and CMI (survey question 10). In addition, as a result of skew measures of -1.038 on question seven and -1.071 on question nine, non-parametric statistics were used to retest the hypothesis related to the equality of means (Kohler 2002), (see Exhibit 6 for skew measures). There were no significant differences between online student answers and in-class student answers using Mann-Whitney $\mathrm{U}$ and Wilcoxon $\mathrm{W}$ tests with $95 \%$ confidence.

Exhibit 8: Content Based Learning Objectives - Online vs. In-Class

\begin{tabular}{|l|c|c|c|c|c|}
\hline \multicolumn{1}{|c|}{ Survey Question and Number } & Mean Online & Mean In- Class & SD Online & SD In- Class & t-Test* \\
\hline $\begin{array}{l}\text { 7. The use of this case supplemented my understanding } \\
\text { of value chain analysis (VCA) concepts. }\end{array}$ & 4.24 & 4.37 & .953 & .572 & .408 \\
\hline $\begin{array}{l}\text { 8. Using the case made coverage of cost and } \\
\text { management accounting concepts more interesting. }\end{array}$ & 3.76 & 3.89 & .935 & .971 & .493 \\
\hline 9. The project gave me useful experience with VCA. & 4.22 & 4.20 & .671 & .654 & .850 \\
\hline $\begin{array}{l}\text { 10. Because of the project I better understand the } \\
\text { relationship between VCA and contribution margin } \\
\text { income statements. }\end{array}$ & 4.07 & 3.76 & .828 & .736 & .051 \\
\hline $\begin{array}{l}\text { 11. After working with the case I am more competent at } \\
\text { building a VCA. }\end{array}$ & 4.07 & 4.11 & .666 & .605 & .746 \\
\hline Content Average & 4.07 & 4.07 & & & \\
\hline
\end{tabular}

* Cannot reject the null hypothesis using a non-directional student's t-test (2 tailed) with $95 \%$ confidence $(\alpha=5 \%)$ unless indicated.

Exhibit 9: Bloom's Educational Objectives - Online vs. In-Class

\begin{tabular}{|c|c|c|c|c|c|}
\hline Survey Question and Number & Mean Online & Mean In-Class & SD Online & SD In Class & t-Test* \\
\hline \multicolumn{6}{|l|}{ Lower Order Thinking } \\
\hline $\begin{array}{l}\text { 12. The case increased my knowledge related to } \\
\text { VCA terms and definitions. (Knowledge) }\end{array}$ & 4.24 & 4.24 & .773 & 639 & .990 \\
\hline $\begin{array}{l}\text { 13. The case required me to describe and explain } \\
\text { VCA principles and theories. (Comprehension) }\end{array}$ & 4.12 & 4.02 & .672 & .715 & .477 \\
\hline Lower Order Average & 4.18 & 4.13 & & & \\
\hline \multicolumn{6}{|l|}{ Higher Order Thinking } \\
\hline $\begin{array}{l}\text { 14. The case required me to apply VCA methods } \\
\text { to a specific data set. (Application) }\end{array}$ & 4.22 & 4.24 & .618 & .480 & .865 \\
\hline $\begin{array}{l}\text { 15. The case gave me practice at decomposing a } \\
\text { production process and reorganizing its structure. } \\
\text { (Analysis) }\end{array}$ & 4.27 & 4.09 & .552 & .590 & .103 \\
\hline $\begin{array}{l}\text { 16. The case enabled me to formulate and design } \\
\text { a more efficient production process based upon } \\
\text { the concepts of VCA. (Synthesis) }\end{array}$ & 4.19 & 4.13 & .682 & .542 & .649 \\
\hline $\begin{array}{l}\text { 17. The case helped me to make evaluations and } \\
\text { judgments about value added and non-value } \\
\text { added production activities. (Evaluation) }\end{array}$ & 3.98 & 4.07 & .881 & .611 & .591 \\
\hline Higher Order Average & 4.17 & 4.13 & & & \\
\hline Bloom's Average & 4.17 & 4.13 & & & \\
\hline
\end{tabular}

* Cannot reject the null hypothesis using a non-directional student's t-test (2 tailed) with $95 \%$ confidence $(\alpha=5 \%)$ unless indicated.

\section{Bloom's Educational Objectives}

Once again, the survey results indicate that the respondents reported little difference between online and inclass learning organized by Bloom's taxonomy of educational objectives. This provides further evidence that lower level learning skills as well as higher-level learning skills can be taught online. Exhibit 9 displays the survey results. 


\section{Summary, Conclusions and Future Research Directions}

\section{Summary}

Generally, there were only small differences in learning between asynchronous online students and in-class students who worked in teams on the case study. Testing 19 hypotheses related to content, Bloom's taxonomy, and overall learning resulted in a significant difference on only one hypothesis.

However, some differences were discovered. For example, online students were better prepared since they had more professional experience (5.49 vs. 3.7 for in-class students) and a greater number of them were accounting majors (32.2\% vs. $13 \%$ for in-class students). In spite of this advantage, online students scored lower on the test questions $(92.9 \%$ vs. $95.9 \%$ for in-class students). This difference is not statistically significant using a t-test with 95\% confidence. Online students worked harder on the case with 9.2 hours of effort vs. 5.71 hours for in-class students but scored slightly lower on the case grade (see Exhibit 4). In addition, significantly more online students withdrew from the course. Finally, online students reported that they learned more than in-class students on survey questions 9,10 and 13.

\section{Conclusions}

The findings of this study support prior research. For example, online and in-class students performed similarly on assignments and exams. Perceptions of learning were equal but self selected online students had a stronger background before taking the course. Exhibit 10 displays an overview of this study.

\section{Exhibit 10: Research Design and Results}

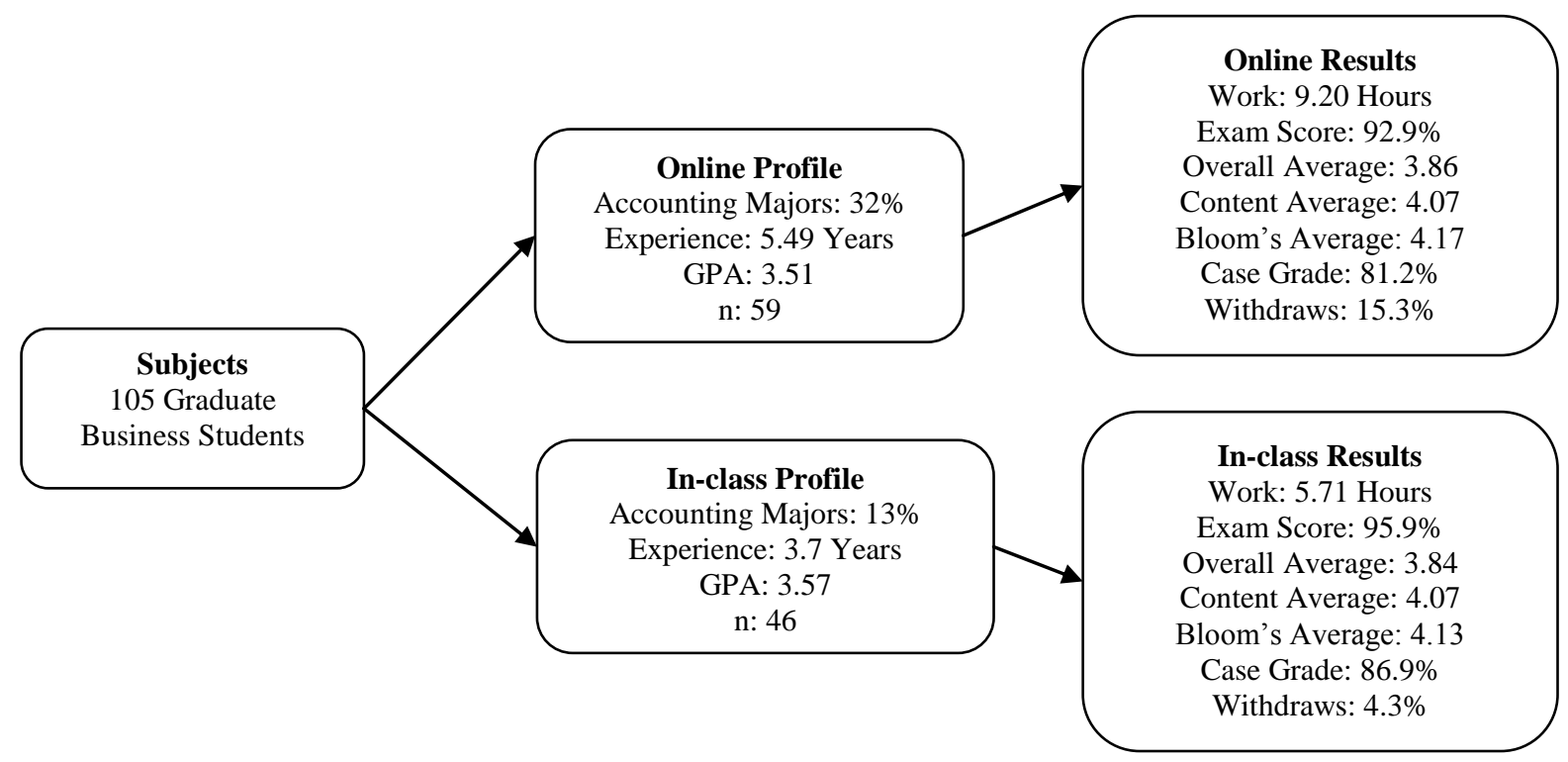

An examination of Exhibit 10 reveals that the online students may have been significantly better prepared for the course since they had more professional experience and there were a greater percentage of accounting majors studying online. However, the learning results were similar even though online students spent significantly more time working on the case. This may indicate that online learning is less efficient than in-class learning. This result is consistent with the findings of (Schulman \& Sims 1999) who posit that better prepared students self select into online courses. Accordingly, poorly prepared students may favor the familiarity of traditional education. 
Even though online students may be better prepared for the course their withdrawal rate is much higher than in-class students. This leads me to conclude that online courses may not be appropriate for weak students. On a positive note, self perceived learning and grades were similar between online and traditional students. This may indicate that management and accounting concepts such as value chain analysis and contribution margin income can be taught online effectively even if cyber-learning is not as efficient as traditional education.

In conclusion, a faculty member that embraces online education should consider the possibility that retention rates may be lower online. In addition, universities may want to mitigate the lower retention rates with support services and policies that assist online students. For example, a university may want to limit online courses to academically stronger students and provide them with close mentoring support. In spite of the disadvantages, online courses in accounting can be delivered effectively and higher order thinking skills can probably be taught in cyberspace.

\section{Future Research}

The results reported in this paper justify more research. Classifying test questions around Blooms taxonomy and analyzing the differences between online and in-class students by taxonomy category would add more insight to this important issue. For example, it would help the analysis to design objective measurement tools such as multiple choice questions and matching questions to evaluate student performance around Bloom's taxonomy.

An investigation using multiple cases, instructors, classes, and universities with random selection of subjects would improve the study. In addition, the sampling methodology and research design could be improved by employing double-blind random assignment into the online and in-class treatments to increase the validity of the study (Judd, Smith and Kidder 1991).

The consideration of team effects may add value to the analysis. Group dynamics on case studies could be investigated to see how this factor has an effect on student performance online. In addition, it would be interesting to measure the nature of the professional experience and how that experience interacts with online learning and group dynamics. A study could setup experience as a control variable to analyze its effect on academic achievement and perceived learning.

This research builds the foundation for empirical work and a more exhaustive investigation of differences and similarities between traditional and online students. The results of this research may be used to design better assessment tools to gauge how online students are learning when compared to their in-class peers. As more business and accounting classes are being offered online, researchers must investigate quality issues to help maintain the academic integrity of higher education.

\section{Acknowledgements}

I thank David F. Bean at Iona College for the helpful comments he supplied at the 2003 Northeast American Accounting Association (AAA) Meeting. I also appreciate the insightful comments by the referees and participants at the 2003 AAA National Meeting of the Artificial Intelligence and Emerging Technologies section.

\section{References}

1. Adams, Bruce (2003). Online Learning Can Reduce Training Costs. Hotel and Motel Management, vol. 218, iss. 17, October, pp. 40-44.

2. Allen, I. Elaine and Jeff Seaman (2003). Sizing the Opportunity: The Quality and Extent of Online Education in the United States, 2002 and 2003. The Sloan Center for Online Education, Needham, MA.

3. Anonymous (2003). Many Administrators believe Online Education Will Soon Edge In-Class Instruction, Report Says. The Chronicle of Higher Education, vol. 50, iss. 4, September 19, pp. 30.

4. $\quad$ Alreck, P. L., and Robert B. Settle. 1995. The Survey Research Handbook, second edition. Chicago, IL: Irwin. 
5. Amlie, T. T. (2002). Self-Selection Bias In On-Line Accounting Courses: Student Characteristics. International Business and Economics Research Conference Proceedings, Las Vegas, Nevada, October.

6. Atkinson, A. A., R. D. Banker, R. S. Kaplan, and S. M. Young. (2001). Management Accounting. Englewood Cliffs, NJ: Prentice Hall.

7. Beard, Lawrence A. and Cynthia Harper (2002). Student Perceptions of Online Versus On Campus Instruction. Education, vol. 122, iss. 4, Summer, pp. 658-664.

8. Bennet, Johanna (2000). The Best Way to Take Classes. Wall Street Journal, November 27, pp. R36.

9. Bloom, B. S., M. D. Engelhart, E. J. Furst, W. H. Hill, and D. R. Krathwohl. (1956). Taxonomy of Educational Objectives, Handbook I: Cognitive Domain. New York, NY: Longman Publishers.

10. Bonner, S. E. (1999). Choosing Teaching Methods Based on Learning Objectives: An Integrated Framework. Issues in Accounting Education. (February): 11-39.

11. Bransford, John, Bob Plants, Nancy Vye, and Kay Burgess. (2003). Three AMIGO(3)s: Using Anchored Modular Inquiry to Help Prepare Future Teachers. Educational Technology, Research and Development, vol. 51, issue 1, pp. 105-120.

12. Clarke, D. (1999). Getting Results with Distance Education. The American Journal of Distance Education, Vol. 12, No.1 pp. 38-51.

13. Conhaim, Wallys W. (2003). Education Ain't What It Used to Be. Information Today, vol. 20, iss. 11, December, pp. 37-41.

14. Cooper, Linda W. (2001). A Comparison of Online and Traditional Computer Application Classes. T. H. E. Journal, vol. 28, iss. 8, March, pp. 52-56.

15. Dobrin, J. (1999). Who's Teaching Online? ITPE News, Vol. 2, Issue 12, June 22 pp. 6-7.

16. Dominguez, Paula Szulc and Dennis Ridley (1999). Reassessing the Assessment of Distance Education Courses. T. H. E. Journal, vol. 27, iss. 2, September, pp. 70-74.

17. Gagne, Margret and Morgan Shepherd (2001). Distance Learning in Accounting. T. H. E. Journal, vol. 28, iss. 9, April, pp. 58-62.

18. Gainen, J. and P. Locatelli. (1995). Assessment for the New Curriculum: A Guide for Professional Accounting Programs. Accounting Education Change Commission and AAA Accounting Education Series, Volume 11.

19. Gold, Martha (2003). IRS Goes E. $T+D$, vol. 57, iss. 5, May, pp. 76-84.

20. Hinkle, Dennis E., William Wiersma and Stephen G. Jurs (1988). Applied Statistics for the Behavioral Sciences. Houston Mifflin, Boston, MA.

21. Hoare, Stephen (2003). Online Studying is Allowing Graduates to Continue in Education While Working. The Guardian, August 26, pp. 19.

22. Hoffman, K. M. (1999). What Are Faculty Saying? eCollege.com.

23. Horngren C. T., G. Foster, and S. M. Datar. (2000). Cost Accounting. Englewood Cliffs, NJ: Prentice Hall.

24. Horngren, C. T., and G. L. Sundem. (1999). Introduction to Management Accounting. Englewood Cliffs, NJ: Prentice Hall.

25. Judd, C. M., E. R. Smith, and L. H. Kidder. (1991) Research Methods in Social Relations. London, UK: Holt, Rinehart and Winston.

26. Keller, Gerald and Brian Warrack. (2003). Statistics for Management and Economics. London, UK: SouthWestern and Thompson Learning.

27. Kohler, Heinz. (2002). Statistics for Business and Economics. London, UK: South-Western and Thompson Learning.

28. Kuh, George D. (2003). What We're Learning about Student Engagement from the National Survey of Student Engagement. Change, vol. 35, March/April, issue 2, pp. 24-32.

29. Marsden, Anne-Michelle (2003). Online Education: New Rules, New Rewards. Journal of Family and Consumer Sciences, vol. 95, iss. 4, November, pp. 8-12.

30. Navarro, P. \& Shoemaker, J. (1999). The Power of Cyberlearning: An Empirical Test. Journal of Computing in Higher Education.

31. Nichols, James, Barbra Shaffer, and Karen Shockey (2003). Changing the Face of Instruction: Is Online or In-Class More Effective. College and Research Libraries, vol. 64, iss. 5, September, pp. 5.

32. Porter, M. E. (1991). Toward a Dynamic Theory of Strategy. Strategic Management Journal, 12: 95-117. 
33. Roach, Rondald (2003). Survey Says Online Learning Equal to Classroom Instruction. Black Issues in Higher Education, vol. 20, iss. 16, September, pp. 44-46.

34. Rovai, Alfred P. (2001). Building Classroom Community at a Distance: A Case Study. Educational Technology, Research and Development, vol. 49, issue 4, pp. 4-15.

35. Rudavsky, Shari (2003). Student Look Online for Degrees. Boston Globe, September 14, pp. B6.

36. Ryan, Richard C. (2000). Student Assessment Comparison of Lecture in an Online Construction Equipment and Methods Class. T. H. E. Journal, Vol. 27, iss. 6, January, pp 78-84.

37. Sakuria, Jennifer, M. (2002). Traditional vs. Online Degrees. E-Learning, vol. 3, iss. 8, Aug/Sep., pp. 2832.

38. Schulman, A. H. \& Sims, R. L. (1999). Leraning in an Online Format Versus an In-Class Format: An Experimental Study. T.H.E. Journal, Vol 26, No.11, June, pp.54-56.

39. SLN (2002). State University of New York Learning Network. www.sln.suny.edu.

40. Smeaton, A. \& Keogh, G. (1999). An Analysis of the Use of Virtual Delivery of Undergraduate Lectures. Computers and Education, Vol. 32 pp. 83-94.

41. Stevens, James. (1986). Applied Multivariate Statistics for the Social Sciences. Hillsdale, New Jersey: Lawrence Erlbaum Associates.

42. Sutherland, T. (1998). Faculty Development Update. Accounting Education News. American Accounting Association, Late Fall: 16.

43. Tribune Newspapers (2003). Class at Home; Online Education Surges, But Some Aren’t Impressed. Chicago Tribune, August 25, pp. 40.

44. Tribunella, Thomas. (2003). Learning Based on Blooms Taxonomy of Educational Objectives: Online Compared to In-Class Students. Proceeding of the Northeast American Accounting Association Meeting, April.

45. Tribunella, Thomas. (2003). Measuring Online Learning in Accounting Courses Using Bloom's Taxonomy. Collected Papers of the Twelfth Annual Research Workshop on: Artifitial Intelligence and Emerging Technologies in Accounting, Auditing and Tax, August.

46. Troy, Leo, (2001). Business and Industrial Financial Ratios. Englewood Cliffs, NJ: Prentice Hall.

47. Wang, Minjuan, Donald A. MacArthur and Bob Crosby (2003). A Descriptive Study of Community College Teacher's Attitudes Toward Online Learning. TechTrends, vol. 47, iss. 5, Sep/Oct., pp. 28-33.

\section{Appendix I: Student Survey for Case Study Evaluation Sun Mountain Products Case Study Acc 520 - Accounting for Managers}

The professor will use this survey to evaluate the effectiveness of the Sun Mountain Products Case that you recently submitted as the group project.

Instructions:

- $\quad$ Please indicate your answers to the case evaluation questions listed below by selecting a single score (1, 2, 3 , etc...) per question.

- $\quad$ Feel free to make comments about the Sun Mountain Products Case after your answer to the objective questions.

- Your answers will not be graded, feel free to express your opinion. Your honesty and insights will help to improve the case in the future.

- $\quad$ Each question allows for 1 response, various choices are listed below each question.

\section{Case Understandability}

1. The case study was clear.

Strongly disagree

1

2

$\mid$

$\frac{3}{\text { Neutral }}$

\begin{tabular}{|c|c}
4 & 5 \\
\hline Agree & Strongly agree
\end{tabular}


2. I was able to understand the case without significant difficulty.

\begin{tabular}{c|c|c|c|c}
1 & 2 & 3 & 4 & 5 \\
\hline Strongly disagree & Disagree & Neutral & Agree & Strongly agree
\end{tabular}

3. The case was well organized.

\begin{tabular}{c|c|c|c|c}
1 & 2 & 3 & 4 & 5 \\
\hline Strongly disagree & Disagree & Neutral & Agree & Strongly agree
\end{tabular}

\section{Case Grading and Fairness}

4. The grade percent allocated to the case study was an appropriate weight given the work required.

\begin{tabular}{c|c|c|c|c}
1 & 2 & 3 & 4 & 5 \\
\hline Strongly disagree & Disagree & Neutral & Agree & Strongly agree
\end{tabular}

5. The level of difficulty of the case was appropriate.

\begin{tabular}{c|c|c|c|c}
1 & 2 & 3 & 4 & 5 \\
\hline Strongly disagree & Disagree & Neutral & Agree & Strongly agree
\end{tabular}

6. The case should continue to be used in this course.

\begin{tabular}{c|c|c|c|c}
1 & 2 & 3 & 4 & 5 \\
\hline Strongly disagree & Disagree & Neutral & Agree & Strongly agree
\end{tabular}

\section{Case Educational Impact}

7. The use of this case supplemented my understanding of value chain analysis concepts.

\begin{tabular}{c|c|c|c|c} 
7. The use of this case supplemented my understanding of value chain analysis concepts. \\
1 & 2 & 3 & 4 & 5 \\
\hline Strongly disagree & Disagree & Neutral & Agree & Strongly agree
\end{tabular}

8. Using the case made coverage of cost and management accounting concepts more interesting.

\begin{tabular}{c|c|c|c|c}
1 & 2 & 3 & 4 & 5 \\
\hline Strongly disagree & Disagree & Neutral & Agree & Strongly agree
\end{tabular}

9. The project gave me useful experience with Value Chain Analysis (VCA).

\begin{tabular}{c|c|c|c|c}
1 & 2 & 3 & 4 & 5 \\
\hline Strongly disagree & Disagree & Neutral & Agree & Strongly agree
\end{tabular}

10. Because of the project I better understand the relationship between VCA and contribution margin income statements.

\begin{tabular}{c|c|c|c|c}
1 & 2 & 3 & 4 & 5 \\
\hline Strongly disagree & Disagree & Neutral & Agree & Strongly agree
\end{tabular}

11. After working with the case I am more competent at building a VCA.

\begin{tabular}{c|c|c|c|c}
1 & 2 & 3 & 4 & 5 \\
\hline Strongly disagree & Disagree & Neutral & Agree & Strongly agree
\end{tabular}

12. The case increased my knowledge related to VCA terms and definitions.

\begin{tabular}{c|c|c|c|c}
1 & 2 & 3 & 4 & 5 \\
\hline Strongly disagree & Disagree & Neutral & Agree & Strongly agree
\end{tabular}

13. The case required me to describe and explain VCA principles and theories.

\begin{tabular}{c|c|c|c|c}
1 & 2 & 3 & 4 & 5 \\
\hline Strongly disagree & Disagree & Neutral & Agree & Strongly agree
\end{tabular}

14. The case required me to apply VCA methods to a specific data set.

$\mid 2$


Strongly disagree

Disagree

Neutral

Agree

Strongly agree

15. The case gave me practice at decomposing a production process and reorganizing its structure.

\begin{tabular}{c|c|c|c|c}
1 & 2 & 3 & 4 & 5 \\
\hline Strongly disagree & Disagree & Neutral & Agree & Strongly agree
\end{tabular}

16. The case enabled me to formulate and design a more efficient production process based upon the concepts of VCA.

\begin{tabular}{c|c|c|c|c}
1 & 2 & 3 & 4 & 5 \\
\hline Strongly disagree & Disagree & Neutral & Agree & Strongly agree
\end{tabular}

17. The case helped me to make evaluations and judgments about value added and non-value added production activities.

\begin{tabular}{c|c|c|c|c}
1 & 2 & 3 & 4 & 5 \\
\hline Strongly disagree & Disagree & Neutral & Agree & Strongly agree
\end{tabular}

\section{Overall Evaluation}

18. Overall, I think the Sun Mountain Products case study is a useful project.

\begin{tabular}{c|c|c|c|c}
1 & 2 & 3 & 4 & 5 \\
\hline Strongly disagree & Disagree & Neutral & Agree & Strongly agree
\end{tabular}

19. The amount of work on the case was justified based on the learning derived.

\begin{tabular}{c|c|c|c|c}
1 & 2 & 3 & 4 & 5 \\
\hline Strongly disagree & Disagree & Neutral & Agree & Strongly agree
\end{tabular}

\section{Additional Information}

20. How many years of professional work experience do you have?

\begin{tabular}{c|c|c|c|c}
1 & 2 & 3 & 4 & 5 \\
\hline 0 & 1 to 3 & 4 to 6 & 7 to 9 & 10 or greater
\end{tabular}

21. What was the total time in hours that you personally spent on this case study?

\begin{tabular}{c|c|c|c|c}
1 & 2 & 3 & 4 & 5 \\
\hline 0 to 3 & 4 to 6 & 7 to 9 & 10 to 12 & 13 or more
\end{tabular}

